\title{
Aspects of Statistics on Innovation in Latvia and Some Guidelines for Its Effective Use
}

\author{
Svetlana Jesilevska \\ University of Latvia, Central Statistical Bureau of Latvia
}

\begin{abstract}
Statistical data on innovation in Latvia, at a current stage, were applied only to the particular areas of developing and planning of Latvian innovation support strategies. The aim of the paper is to show Latvian innovative performance and to provide proposals on making statistical data on innovations more useful for the analysis of innovativeness of Latvia. Research methods: bibliography review and methods of statistical analysis, such as processing and comparative analysis.
\end{abstract}

Keywords - Community innovation survey, innovations, statistical data on innovations.

\section{INTRODUCTION}

The quality and amount of available statistical data have extremely increased in the past decades. In this context, Botero states that the knowledge how to use these data effectively should be greatly improved (Botero et al., 2012).

The author did not find any studies of Latvian researchers about the relevance of statistical data on innovation for a broad analysis of Latvian innovative performance and finally for development of Latvian innovation support strategies. That is why the present study performed by the author is a significant contribution to the analysis of the suitability of statistical data on innovation for a comprehensive analysis of Latvian innovative performance.

The aim of the paper is to show Latvian innovative performance on the basis of statistical data and to provide proposals on making statistical data on innovations more useful for the analysis of innovativeness of Latvia.

To achieve the aim, qualitative and quantitative methods of research have mainly been used, such as processing and comparative analysis.

The main tasks of the paper:

- to examine innovative performance of Latvian enterprises on the basis of recent statistical results;

- to indicate problems of innovativeness in Latvia;

- to provide certain directions of making the statistical data on innovations more useful for the analysis of Latvian innovative performance.

\section{THE USE AND USERS OF THE INNOVATION SURVEY DATA}

Two approaches of data collection are distinguished in scientific literature. The object approach focuses on individual innovations. Smith and Arundel clarify that the subject approach focuses on the innovating enterprise and involves carrying out a survey of a country's enterprises with the purpose to identify enterprises, which have introduced innovations during a given period of time (Smith, 1992; Arundel et al., 1995).
Today a large majority of countries carry out innovation surveys with a subject approach. Innovation surveys are known as the Community Innovation Surveys (CIS). In order to have an accurate picture of the innovation situation in Latvia, since 2002 the Central Statistical Bureau of Latvia regularly participates in the Community Innovation Survey.

The Community Innovation Survey is a rich and direct source of information on enterprises' innovation activities and the economic environment in which they take place. The Community Innovation Surveys are conducted biannually and cover a 3-year reference period. The Community Innovation Survey data are collected at the enterprise level.

The EU and the OECD countries rely on the Oslo Manual (OECD. Eurostat, 2005) definitions and guidelines that ensure international comparability of data based on innovation survey.

Despite the fact that the common methodology is developed, according to the research of Es-Sadki, there are still some concerns with the Community Innovation Survey data comparability across countries:

- concept of innovation differs across countries;

- response rates differ;

- market concept differs;

- different sectors are covered;

- different size thresholds;

- differences in survey design (voluntary vs mandatory survey, non-response surveys and use of imputation, online vs personal interviews/postal);

- $\quad$ use of combined surveys (e.g., R\&D/innovation);

- different questionnaire design (e.g., filtering of noninnovators);

- the influence of cultural and linguistic factors on the Community Innovation Survey answers is still not well understood (Es-Sadki, 2014).

Nevertheless, the Community Innovation Survey data in combination with other statistical survey data can give answers to some very essential support policy questions, such as:

- impact of innovation activity on economic growth;

- $\quad$ effect of innovation activity on export, employment, etc.;

- impact of government support on innovation activity;

- the persistence and the dynamics of innovation;

- insight into sources of information for innovation, into knowledge acquisition, cooperation strategies, types of innovation, etc.

Microdata-based indicators allow differentiating enterprises by their size, industry, etc., but econometric approach allows estimating functional relationships between the variables, 
which could be different across sub-groups of enterprises. The statistical data on innovation received from the Community Innovation Survey is supplemented by statistics from other sources, e.g., the Organisation for Economic Co-operation and Development (OECD) and the World Bank.

The Community Innovation Survey data in practice can be used just to evaluate the past innovation activity and to decide whether the past innovation support strategies were efficient or not. Practically no methodology exists to predict an innovation activity for future because in reality innovation status of an enterprise can change very rapidly from non-innovative to innovative, for example, due to the receipt of a subsidy and vice versa.

The several categories of the Community Innovation Survey data users can be distinguished:

- institutions at the European level (the European Commission, the European Parliament, the European Central Bank and other European agencies);

- institutions at the national or regional levels (Ministries of Economics, Ministries of Finance, Ministries of Education and Science, National Statistical Offices, etc.);

- international organisations (the Organisation for Economic Co-operation and Development (OECD), the United Nations, the International Monetary Fund, the International Labour Organisation, etc.);

- $\quad$ researchers and students - for research and analyses;

- $\quad$ social actors at the European, national or regional levels: employers' associations, trade unions, lobbies, etc.;

- international, national or regional media - interested both in data and analyses or comments as media are the main channels of statistics to the general public;

- enterprises - for their own market analysis and their marketing strategy (especially for large enterprises) or because they offer consultancy services.

At the European level, main users are consulted regularly (at task forces, ad hoc meetings) for their needs and are involved in the process of the development of the model questionnaires at a very early stage. User needs are considered throughout the whole discussion process of the model questionnaires in order to provide relevant statistical data for monitoring and benchmarking of European policies (The Community Innovation Survey 2012 quality reporting). Deiss indicates that at the EU level, the Community Innovation Survey data are relevant for Framework programmes / Horizon 2020; Sectoral policies; SME policies; Innovative public procurement; Fiscal incentives; ECO-Innovation (Deiss, 2014).

According to Es-Sadki (2014) (see Fig. 1), data number of research papers using Community Innovation Survey data is not high. The number of research papers using Community Innovation Survey data increased steadily during 2010-2013. In 2014 the number of papers using Community Innovation Survey data fell dramatically.

In practice, access to the innovation survey data, as with access to microdata, can be problematic for researchers who do not work for a ministry or the official statistical office. For example, new microdata release normally takes place two and half years after the end of the survey reference period. As a result, it is still important to define a boundary between the confidentiality of the microdata disclosed in the survey, which statistical offices should guarantee by law and a broader use of these data for research and econometric analyses.

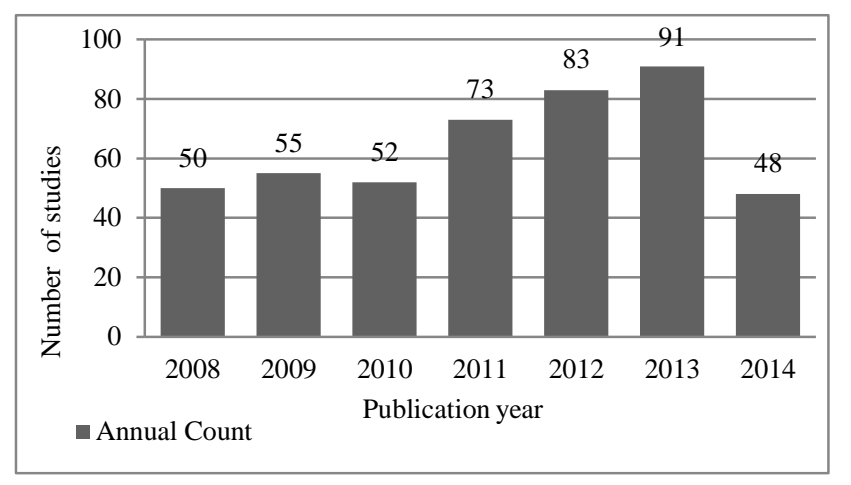

Fig. 1. Papers using CIS data (2008-2014) (the author's chart based on EsSadki, 2014).

There are two types of releases of the Community Innovation Survey microdata for scientific purposes. The Community Innovation Survey microdata can be accessed via CD-ROMs (scientific-use files) and in the SAFE Centre at Eurostat's premises in Luxembourg. The both possibilities meet the same requirements: an authorised researcher has the right to use anonymised microdata of the Community Innovation Survey for an agreed research project. This possibility depends on overall microdata availability at Eurostat as Member States decide to allow the Community Innovation Survey microdata to be offered for the research use and give the permission for using the microdata for the particular research project (Anonymisation of Community Innovation Survey 2010 microdata, 2014).

According to the results of policy makers' interviews performed by Es-Sadki (2014), several countries use the Community Innovation Survey data in their national strategies, for example, Denmark, Spain, Romania, Finland, Malta, Estonia, and the United Kingdom. According to Es-Sadki (2014), the Community Innovation Survey is used for policy but almost all countries note that the Community Innovation Survey is not the only source: for adjusting policy (Austria, Hungary, Malta, Estonia, etc.); for developing policy (Spain, Romania, Finland, Hungary, Malta, Estonia, etc.). Latvia is not among the countries that use the Community Innovation Survey data in their national innovation support strategies.

According to the results of the survey for the Community Innovation Survey 2016 Task Force, conducted by the United Nations University - Maastricht Economic and Social Research Institute on Innovation and Technology (UNUMERIT) and Eurostat, Latvian policy makers find relevant for policy-making in Latvia only 9 questions from the Community Innovation Survey 2014 Questionnaire:

- During the three years from 2012 to 2014, did your enterprise introduce: goods innovations / service innovations?

- During the three years from 2012 to 2014, did your enterprise introduce: new or significantly improved 
methods / logistics / supporting activities for your processes?

- During the three years from 2012 to 2014, did your enterprise engage in the following innovation activities: in-house $R \& D$, external $R \& D$, design, etc.?

- How much did your enterprise spend on each of the following innovation activities in 2014 only? In-house, external, acquisition of machinery, etc.

- During the three years from 2012 to 2014, did your enterprise introduce: new business practices for organising procedures, organising work, organising external relation?

- During the three years from 2012 to 2014, did your enterprise introduce: changes to aesthetic design, new media or techniques, product placement, etc.?

- Intellectual property rights and licensing apply for patent, utility model etc.

- What was your enterprise's average number of employees in 2012 and 2014 ?

- What was your enterprise's total turnover for 2012 and 2014 ?

The Community Innovation Survey 2014 contained 35 questions from which more than 100 variables were calculated.

According to the results of the survey for the Community Innovation Survey 2016 Task Force, conducted by the United Nations University - Maastricht Economic and Social Research Institute on Innovation and Technology (UNUMERIT) and Eurostat, in Latvia statistical data on innovation were mainly used for:

- developing new programmes for EU funding period of 2014-2020;

- the regular Report on Economic Development of Latvia;

- Guidelines for Science, Technology, and Innovation for 2014-2020 (Framework of Smart Specialisation Strategy);

- the corporate income tax incentive for $R \& D$.

\section{How INNOVATIVE IS LATVIA}

Results of the last statistical survey on innovation in Latvia show that during the reference period of 2010-2012 about $30.4 \%$ of surveyed enterprises were innovative, to compare in 2008-2010 29.9\% of enterprises were active in innovation (CSP, 2014). In 2010-2012, 64.6\% of large enterprises (more than 250 employees) were innovative, $43.2 \%$ of mediumsized enterprises (50-249 employees) and $26.5 \%$ of small enterprises (10-49 employees) were also innovative (CSP, 2014). Micro enterprises (less than 10 employees) were not surveyed.

During the reference period of 2010-2012, $64 \%$ of innovative enterprises introduced product and process innovations and $36 \%$ introduced organisational and marketing innovations (CSP, 2014).

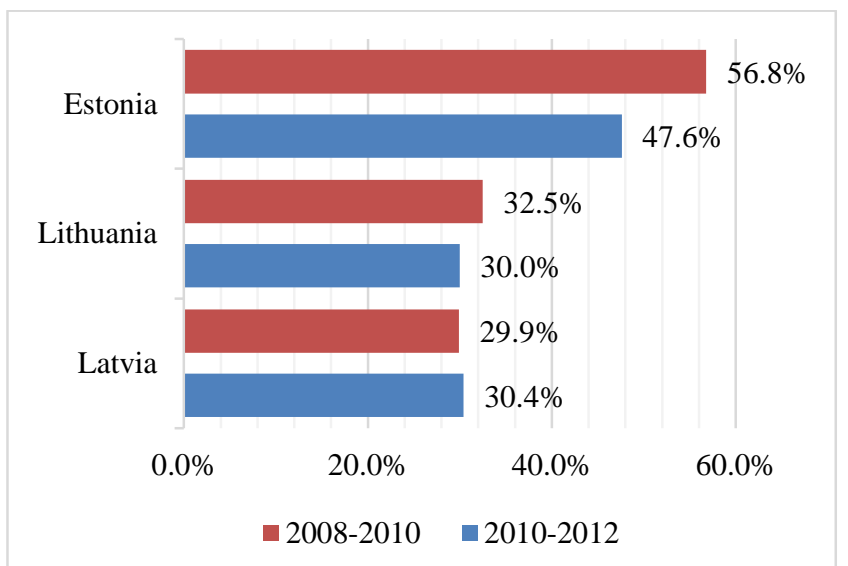

Fig. 2. Innovative activity of Latvia, Lithuania and Estonia (the author's chart based on CSP, 2014).

According to statistical data, in comparison with the Baltic countries, Latvia had the lowest innovative activity (see Fig. 2).

According to Innovation Union Scoreboard 2014 results, Latvia together with Bulgaria and Romania is included in the modest innovators' performance group as its innovation activity level is less than $50 \%$ of the EU average (Innovation Union Scoreboard 2014).

According to Global Innovation Index 2014, Latvia is one of the countries with minimal scores of innovation activities in the industry (The Global Innovation Index 2014 Report).

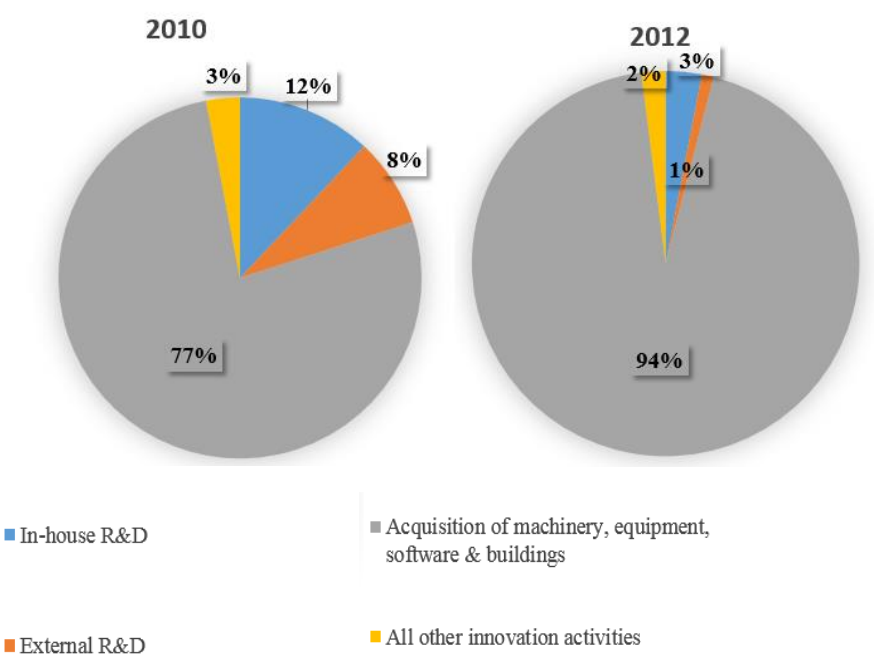

Fig. 3. Expenditures on technological innovation by type of expenditure (as \% of total expenditure on innovation activities) (the author's chart based on CSP, 2014).

In the author's opinion, one of the reasons why innovative activity of Latvia is relatively low is a lack of investments in R\&D. According to the innovation survey results (see Fig. 3), in 2012 only $3 \%$ of total expenditures on innovative activities of enterprises were devoted to in-house R\&D (in $2010-$ $12 \%$ ), at the same time in 2012 considerably much - $94 \%$ of expenditures were devoted to the acquisition of machinery, equipment, software, etc. (CSP, 2014). This means that Latvian enterprises purchase already developed innovative ideas, not develop innovations by themselves. 
The survey data on innovation show that only every fourth enterprise $(25.5 \%)$ during the reference period of 2010-2012 co-operated with other enterprises or institutions for product and process innovation activities. Most of the surveyed enterprises co-operated with other enterprises within their enterprise group ( $57 \%$ ), the nest popular co-operation partners were suppliers of equipment, materials, components, or software (44\%). Most rarely enterprises co-operate with universities or other higher research institutions and with government, public or private research institutions (CSP, 2014). Lack of co-operation with universities or research institutions confirms the problem that Latvian enterprises do not participate in the development of innovation.

Co-operation between enterprises and scientists and researchers is especially essential as they complement each other in different ways. Branstetter and Hyeog clarify the essence of the co-operation between enterprises and scientists. In their view, scientists actually produce an invention product or prototype - and they then seek to license the technology to an enterprise. In this case, the function of the enterprise is to develop the product to the mass-production stage and market it. In collaborative implementation, both scientists and entrepreneurs contribute to the research stage. In this case, the university conducts the research, while the entrepreneur focuses on development, marketing, and production (Branstetter \& Hyeog, 2004).

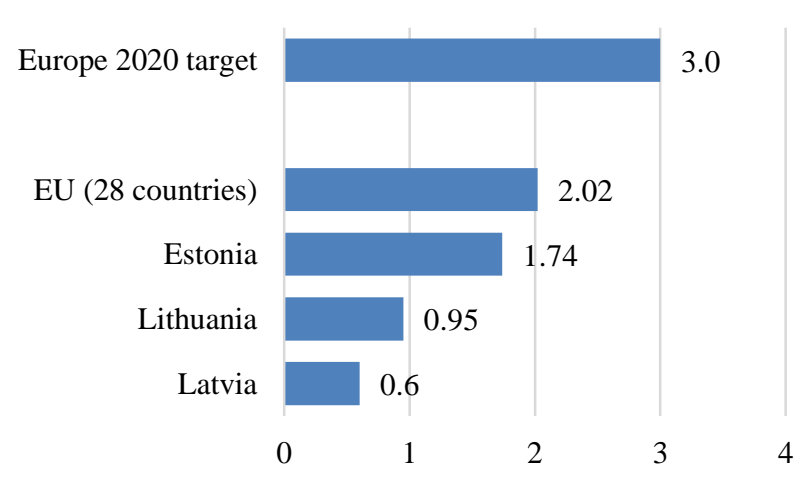

Fig. 4. Situation of countries with regard to its R\&D intensity target (the author's chart based on the data of Eurostat).

Figure 4 presents the latest available 2013 estimates placing Latvia into an international context with regard to R\&D expenditures as a percentage of GDP. It shows the R\&D expenditures of individual Baltic countries as a percentage of GDP, as well as the average for the EU-28, compared with the Europe 2020 target of $3 \%$. The Latvian R\&D expenditures represented $0.6 \%$ of GDP in 2013 - one of the smallest shares in the EU. Latvia has set a national target to bring R\&D expenditures to $1.5 \%$ of GDP by 2020; in comparison, the EU has set a target of $3 \%$. According to the report of Swedbank analysts, yet there is no concrete activity plan in Latvia for achieving these goals. If Latvian government measures remain short-term oriented, enterprises are unlikely to see this as an inviting strategy for R\&D investments (Macro Research. Swedbank, 2014).

The author believes that innovation support strategies should take into consideration all particular qualities of national innovation system in the country. In the author's opinion, informational support, including statistical data, is a very important factor for well-functioning of the Latvian Innovation System.

According to the statistical data discussed above, the most valuable innovation support strategies for Latvia are the ones that improve co-operation between the enterprises and research institutions in the innovation system and increase the innovative capacity of enterprises. In accordance with the previous research results of the author with the co-operation with professor Daina Škiltere, the most important here is the ability of entrepreneurs to identify and absorb new technologies - the success of Latvian economy depends on the ability and willingness of entrepreneurs to search for and use knowledge produced outside Latvia. This process will require the ability to understand the knowledge and to use it in R\&D activities and to adapt it for creating new knowledge. The investments into this area in Latvia are extremely low and should be supported (Jesil̨evska \& Škiltere, 2013a).

\section{Proposals to IMPRove Process of Statistics ON INNOVATION IN LATVIA}

Innovation policy is not a simple process as the innovation system is dynamic, complex and global. Gault states that it is very difficult to understand the system, but there must be some understanding if an innovation policy works, where 'work' refers to achieving the short- and longer-term objectives and having social impact (Gault, 2011). In today's fast changing, increasingly interdependent world, productive decisions on innovation support strategies require reliable, comparable, and understandable statistical information (Jesil̨evska \& Škiltere, 2013). Statistical data on innovation help learn from the past, understand the present, and make conclusions about the future. The value of statistics on innovation is only as great as the ability to accurately understand, interpret and evaluate the available information.

Survey on innovations in Latvia is performed in accordance with the methodology provided by Eurostat, that is why statistical data on innovations fully meets the needs of European data users (mainly, the European Commission). Innovation survey data do not give insight into the peculiarities of Latvian innovative performance as it does not cover Latvian innovative performance at the regional level and does not cover micro enterprises that are important for the Latvian economy, etc. As a result, there is an unclear vision of the weakest elements in the system to be supported. The author proposes some future directions for innovation measurement, which will make statistics on innovation more suitable for the overall analysis of peculiarities of innovative development in Latvia:

- The Community Innovation Survey data are not available on an annual basis. The Central Statistical Bureau of Latvia collects statistical data on innovation activity but they appear with a time lag, e.g., in 2013 the data were collected for the observation period of 2010-2012. During the time period when the Community Innovation Survey is not conducted, it would be necessary to carry out smaller sample surveys with a smaller number of innovative companies (for example, only for large 
enterprises with 250 and more employees) so as to survey indicators characterising innovative performance (determining the basic indicators of innovative activity which are essential for the development of the innovation support strategies) to obtain operational data.

- The Community Innovation Survey is a sample survey, which does not cover all enterprises and sectors of the business economy. In Latvia it would be extremely useful to develop additional innovation survey to collect and compile time series of data pertaining to innovation activities in the manufacturing sectors. The output from this study shall be used by policy makers for analysing and understanding the diffusion, usage and practice of innovation in the manufacturing sectors of Latvia. This survey could be conducted every year with the reference period of one year. This approach will provide operational statistical data for policy makers.

- In order to make a qualitative analysis of R\&D and innovation activities in the country, data from various sources should be linked together. Aerts and Czarnitzk give an example that in Belgium, in order to evaluate R\&D policy in the country, the Community Innovation Survey data are supplemented with information from the Belfirst database, which contains the annual account data of Belgian firms. Furthermore, the firms are linked to patent data from the European Patent Office (Aerts \& Czarnitzk, 2004).

- In order to increase the number of innovative enterprises, it is necessary to understand what prevents some enterprises from innovating, what barriers they face, to identify strategies to which they would be more sensitive. An essential question for policy makers is how to get non-innovators to be innovative? Actually, the Community Innovation Survey questions are concentrated on innovative enterprises. As a result, policy makers do not have data on reasons why there is so high rate of non-innovators in Latvia. In Community Innovation Surveys, some countries add a few extra questions for national purposes. Latvia can also use this possibility and add some questions essential for national policy makers, e.g., questions for non-innovators.

- The issue of including some questions in the Community Innovation Survey for non-innovative respondents was widely discussed during last year in Eurostat. Finally, it was decided to include some extra questions for noninnovators to the Community Innovation Survey 2014. In the Community Innovation Survey 2014, the respondent will be asked to indicate the reasons why not to innovate.

- The Community Innovation Survey collects data for the Latvian region. Is it possible to formulate successful innovation stimulating strategies in the country without knowing the situation at the regional level? The author believes that it would be useful to develop an additional innovation survey to collect data on innovation activities at the regional level (Kurzeme, Latgale, Vidzeme, Zemgale, Riga regions, etc.).
- Estonia and Latvia conduct innovation surveys that are actually based on the same Eurostat methodology, although innovative performance in Estonia is much better than in Latvia. Estonia participates in the innovation survey for a longer period of time than Latvia and is more experienced in collecting data on innovations. Latvia should co-operate with the Baltic countries to take over our neighbours' good experience.

- The answers to the Community Innovation Survey questions are influenced by the enterprises' subjective perceptions; as a result, the quality of statistical data suffers. The process of collecting statistical data on innovations is too difficult, expensive and timeconsuming and should be simplified. Co-operation between the Central Statistical Bureau of Latvia and other government bodies should be developed.

- Different forms of data dissemination methods should be developed, such as statistical overviews, econometric analyses, presentation and debate, on-line data, etc.

- Innovation survey data should be combined with other data (like patent statistics etc.) for deeper econometric analysis to answer policy questions.

The improvement steps of surveys on innovation in Latvia, changes in the innovation survey questionnaire or additional innovation surveys can be developed by the Central Statistical Bureau of Latvia in co-operation with main Latvian data users (such as the Ministry of Economics of the Republic of Latvia, Ministry of Education and Science).

\section{CONCLUSION AND RECOMMENDATIONS}

In the author's opinion, informational support, including statistical data, is a very important factor for well-functioning of the Latvian Innovation System.

To promote a wider use of statistical data on innovation in Latvia for policy needs, research, etc., co-operation between the Central Statistical Bureau of Latvia and other government bodies as well as respondents (enterprises) should be developed. In order to improve the quality of data on innovation, the Central Statistical Bureau of Latvia should cooperate with more experienced countries in terms of collecting data on innovations.

In Latvia, it might be useful to expand the range of data collected, e.g.:

- to collect and compile time series of data pertaining to innovation activities in the manufacturing sectors;

- to collect data on innovation activities at the regional level (Kurzeme, Latgale, Vidzeme, Zemgale, Riga regions, etc.);

- to add some questions essential for national policy makers, e.g., questions for non-innovators, etc.

The author believes that in the future innovation survey in Latvia could be developed to give insight into peculiarities of the Latvian innovative performance. 


\section{REFERENCES}

Aerts, K. \& Czarnitzk, D. (2004). Using Innovation Survey Data to Evaluate $R \& D$ Policy: The Case of Belgium. Discussion Paper No. 04-55. Centre for European economic Research. Retrieved August 14, 2014, from http://papers.ssrn.com/sol3/papers.cfm?abstract_id=572086

Anonymisation of CIS 2010 microdata. (n.d.). Workshop on Community Innovation Survey, Luxembourg, 30 June to 1 July 2014. Retrieved August 14, 2014, from https://circabc.europa.eu/faces/jsp/extension/wai/navigation/ container.jsp

Botero, J. C., Janse, R., Muller, S. \& Pratt, C.S. (eds.). (2012). Innovations in Rule of Law. The Hague Institute for the Internationalisation of Law and The World Justice Project. Retrieved August 12, 2014, from http://www.hiil.org/data/sitemanagement/media/WJP\&HiiL\%20UN\%20 Report-UNGA\%20Event\%281\%29.pdf

Branstetter, L. \& Hyeog, U. K. (2004). The Restructuring of Japanese Research and Development: The increasing impact of science on Japanese $R \& D$ RIETI Discussion Paper Series 04-E-021. Retrieved August 27, 2014, from http://www.rieti.go.jp/jp/publications/dp/04e021.pdf

CIS 2012 quality reporting. (n.d.). Workshop on Community Innovation Survey, Luxembourg, 30 June to 1 July 2014. Retrieved August 14, 2014 from

https://circabc.europa.eu/faces/jsp/extension/wai/navigation/container.jsp

CSP. (2014). Informatīvais apskats "Inovācijas Latvijā" Retrieved February 20, 2016, from http://www.csb.gov.lv/sites/default/files/nr_37_inovacijas _latvija_14_00_lv.pdf

Database of Eurostat. (n.d.). Retrieved February 20, 2016, from http://ec.europa.eu/ eurostat/data/database

Davis, K. E., Fischer, A., Kingsbury B. \& Merry S. (eds.). (2012). Governance by Indicators: Global Power through Quantification and Rankings, Oxford: Oxford University Press. http://dx.doi.org/10.1093/acprof:oso/9780199658244.001.0001

Deiss, R. (2014). Policy Use of Innovation Data. Workshop on CIS (Community Innovation Survey). Eurostat-Luxembourg. Retrieved August 14, 2014, from https://circabc.europa.eu/faces/jsp/extension/ wai/navigation/container.jsp

Es-Sadki, N. (2014). Policy makers interviews. Workshop on CIS (Community Innovation Survey). Eurostat-Luxembourg. Retrieved August 14, 2014, from https://circabc.europa.eu/faces/jsp/extension/ wai/navigation/container.jsp

Gault, F. (2011). Social Impacts of the Development of Science, Technology and Innovation Indicators. UNU-MERIT Working Paper 2011-008, Maastricht: UNUMERIT. Retrieved August 25, 2014, from http://papers.ssrn.com/sol3/papers.cfm?abstract_id=1949172

Gault, F. (2014). Where are innovation indicators, and their applications, going? UNU-MERIT Working Paper 2014-055, Maastricht: UNUMERIT. Retrieved August 25, 2014, from http://www.merit.unu.edu/publications/working-papers/?year_id=2014
Innovation Union Scoreboard 2014. (n.d.). Retrieved August 27, 2014, from http://ec.europa.eu/enterprise/policies/innovation/files/ius/ius2014_en.pdf

Innovation statistics. Statistics Explained. Eurostat. (n.d.). Retrieved August 27, 2014, from http://epp.eurostat.ec.europa.eu/statistics_explained/ index.php?title=Innovation_statistics\&oldid $=172423$

Jesil̨evska, S. \& Škiltere, D. (2013). Innovative performance and innovation system of Latvia. Regional Formation and Development Studies, 2(10), 211-218.

Jesiḷevska, S. \& Škiltere, D. (2013a). Aspects of properly functioning National Innovation system: the case of Latvia. Societas et iurisprudentia. Slovakia, 1(1), 224-245. http://sei.iuridica.truni.sk/archive/2013/01/SEI2013-01-Studies-Skiltere-Daina-Jesilevska-Svetlana.pdf

Macro Research. Swedbank. (2014). The Latvian Economy. Retrieved August 27, 2014, from https://www.swedbank.lv/files/analitiskie_materiali/ menesa_apskats/The_Latvian_Economy_2014_05_EN.pdf

OECD, Eurostat. (2005). Oslo Manual: Guidelines for Collecting and Interpreting Innovation Data (3rd ed.). Retrieved August 27, 2014, from: http://www.oecd.org/document/33/0,3746,en_2649_34451_35595607 _1_1_1_1,00.html

Smith, K. (1992). Technological Innovation Indicators: Experience and Prospects. Science and Public Policy, 19(6), 383-392. http://dx.doi.org/10.1093/spp/19.6.383

The Global Innovation Index 2014 Report. (n.d.). Retrieved August 27, 2014, from: https://www.globalinnovationindex.org/content.aspx?page=gii-fullreport-2014

Van de Paal, G. \& Soete, L. L. (1995). Innovation Strategies for Europe's Large Industrial Firms: Results of the PACE Survey on Information Source, Public Research, Protection of Innovation and Government Programmes, Final Report. Maastricht: MERIT.

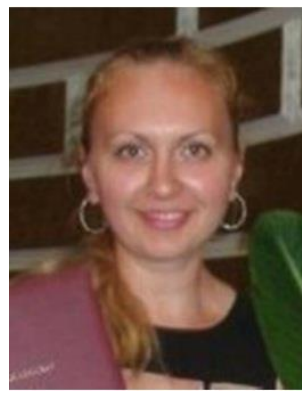

Svetlana Jesilevska holds the Master's degree in Economics. She graduated from the Doctoral study programme on Economics in 2016 autumn. In 2015, she received a Young Statistician Prize of the International Association for Official Statistics (IAOS) for her research "Iterative Method for Reducing the Impact of Outlying Data Points: Ensuring Data Completeness". She works at the Central Statistical Bureau of Latvia, is responsible for methodological aspects of statistics on R\&D and innovation; mathematical, logical and analytical analysis of statistical data; participates in international statistical projects,

Working Group Meetings on Statistics on Science, Technology and Innovation organised by the European Commission Eurostat and OECD Working Party of National Experts on Science and Technology Indicators (NESTI). She is the Author of several papers about methodological aspects of innovation and R\&D statistics.

E-mail: mozir@inbox.lv 